\title{
Evidence from district level inputs to improve quality of care for maternal and newborn health: interventions and findings
}

\author{
Rehana A Salam', Zohra S Lassi', Jai K Das ${ }^{1}$, Zulfiqar A Bhutta ${ }^{1,2^{*}}$
}

\begin{abstract}
District level healthcare serves as a nexus between community and district level facilities. Inputs at the district level can be broadly divided into governance and accountability mechanisms; leadership and supervision; financial platforms; and information systems. This paper aims to evaluate the effectivness of district level inputs for imporving maternal and newborn health. We considered all available systematic reviews published before May 2013 on the pre-defined district level interventions and included 47 systematic reviews.

Evidence suggests that supervision positively influenced provider's practice, knowledge and client/provider satisfaction. Involving local opinion leaders to promote evidence-based practice improved compliance to the desired practice. Audit and feedback mechanisms and tele-medicine were found to be associated with improved immunization rates and mammogram uptake. User-directed financial schemes including maternal vouchers, user fee exemption and community based health insurance showed significant impact on maternal health service utilization with voucher schemes showing the most significant positive impact across all range of outcomes including antenatal care, skilled birth attendant, institutional delivery, complicated delivery and postnatal care. We found insufficient evidence to support or refute the use of electronic health record systems and telemedicine technology to improve maternal and newborn health specific outcomes.

There is dearth of evidence on the effectiveness of district level inputs to improve maternal newborn health outcomes. Future studies should evaluate the impact of supervision and monitoring; electronic health record and tele-communication interventions in low-middle-income countries.
\end{abstract}

\section{Introduction}

District level healthcare is the cornerstone of primary health. An ideal district health system should not only offer primary care services but also provide first level of outpatient care and referrals for more specialized care. They also serve as a nexus between community and facility level care for health information; play a direct role in training health care workers; and provide necessary data to guide national health policy. This role is fundamental to effective health care delivery and failure to recognize the interrelationship between community and district-level facilities might result in inefficiency and fragmented delivery of meaningful public health interventions. Community based intervention impacts

\footnotetext{
* Correspondence: zulfiqar.bhutta@aku.edu

'Division of Women \& Child Health, Aga Khan University, Karachi, Pakistan
} Full list of author information is available at the end of the article discussed in paper 2 of this series [1] could not be achieved if district level priorities do not reflect the needs of the community.

District level facilities play a pivotal role for maternal newborn health $(\mathrm{MNH})$ programs. In some countries, programs like Safe Motherhood Initiative and Integrated Management of Childhood Illness (IMCI) are based on district-level health systems. Outpatient clinics at district hospitals provide primary prevention services for $\mathrm{MNH}$ including universal maternal and childhood immunizations. However these programs may vary in structure and functioning from country to country depending on the healthcare needs and infrastructure. The core components of district level inputs include training, supervision and monitoring of health workers in the peripheral health centers and managing health information systems for strategic planning and monitoring of the district health system. In this paper, we have reviewed the effectiveness of care 
delivered through district level inputs for improving $\mathrm{MNH}$ outcomes. For this review we have broadly categorized these interventions into four categories: governance and accountability mechanisms; leadership and supervision; financial incentives; and information systems.

\section{District level characteristics}

\section{Governance and accountability mechanisms}

Governance is achieved through a combination of strategies including clinical competence, patient involvement, risk management, use of information, staff management, maintaining medical registries, and implementation of continuous quality improvement (CQI) tools. Accountability involves audit and feedback mechanisms that entail a systematic approach to ensure that the services are accountable for delivering quality healthcare. Audits involve any summary of clinical performance of healthcare professionals over a period of time which is presented to them in a written, electronic or verbal format for self-accountability. Healthcare professionals are prompted to modify their practice if the feedback is inconsistent with the standards or accepted guidelines. Audit tools for evaluating maternal and perinatal deaths have been an integral part of quality improvement in obstetric care. These are effective in defining the context specific problem and propose solutions. Although these mechanisms have been used widely as a strategy to improve professional practice, they have not shown consistent effectiveness majorly due to the inconsistencies and variations involved in implementation $[2,3]$.

\section{Leadership and supervision}

Supervision plays a key role in primary healthcare (PHC) service delivery and it requires the district level staff to supervise the public health activities and provide appropriate clinical care [4-6]. Good leadership is also critical to the success of district health systems as it relies on how leaders work together to enable the health system to achieve its goals [7]. It involves strategic planning for the provision of services, resource allocation, and set priorities for improved performance. Aspects of leadership and supervision involve problem solving, reviewing records, observing clinical practice, mentoring and guidance on matters of personal, professional and educational development in context to patient care. Supervision in district health structures is difficult to implement due to time and costs involved and also the increasing numbers of district level facilities in even increasingly remote areas [8]. One of the emerging concepts is the involvement of local opinion leaders in district health leadership to promote knowledge transfer of evidence into practice and ultimately improve health care [9]. Since these individuals are perceived as credible and trustworthy, they may play a key role in assisting individuals to identify the best evidence-based healthcare practice and facilitate behavior change [10].

\section{Financial incentives}

It involves provision of monetary benefits as a source of motivation for performing desired health related actions. Financial interventions are aimed at creating a greater demand for health services and include scale-up of preventive health interventions, as well as provision of free access to basic health care. In recent years there has been an increase in the utilization of financial support platforms to reduce out of pocket client expenditure and strengthen service delivery and utilization at the district level. The targeted health services can include seeking care, behavior modification, immunization, compliance to health professional's clinical behavior and performance. Incentives directed towards care providers include capitation (payment for each patient enrolled), fee for service and pay for performance. Those directed towards users involve conditional cash transfers (CCT), vouchers, health insurance and fee exemptions. Diverse and innovative financial support platforms are being implemented in some of the fragile states such as Cambodia, Afghanistan, Pakistan and Haiti as well as more established economies of Latin American countries $[11,12]$ however, impact on quality of care for $\mathrm{MNH}$ is still emerging [13].

\section{Information system}

It is one of the essential building blocks of health system [14] that captures, manages and transmits information related to the health of individuals or activities of organizations. It involves district level routine information systems, disease surveillance, hospital patient administration, electronic health records, human resource management and communication systems. Health information system is vital for public health decision making, health sector reviews, planning and resource allocation and program monitoring and evaluation. Weak information systems are a critical challenge to achieving the MNH related Millennium Development Goals. The major challenges identified in this domain include issues related to completeness, accuracy and timeliness, especially in low middle income countries (LMIC). These challenges limit its use in routine district health care planning, monitoring, and evaluation. Other factors associated with poor quality data in resource constrained settings include duplicate, parallel reporting channels and insufficient capacity to analyze and use data for decision making. Recently, there is an increased emphasis on utilizing electronic communication systems including mobile phones, telephone based follow-up and counseling, after-hours telephone access, and screening. As the field is still nascent, a limited but growing body of evidence exists to support the role of mobile technologies 
in improving $\mathrm{MNH}$ outcomes [15-17]. Despite the anticipated benefits of mHealth; wide-scale impacts of mHealth on $\mathrm{MNH}$ outcomes need to be explored further $[18,19]$.

We aim to systematically review and summarize the available evidence from relevant systematic reviews on the impact of the outlined district level inputs (panel 1) to improve the quality of care for women and newborns.

\section{Methods}

We considered all available systematic reviews on the pre-defined district level interventions published before May 2013 as outlined in our conceptual framework [20]. A separate search strategy was developed for each component using pre-identified broad keywords, medical subject heading $(\mathrm{MeSH})$, and free text terms: [(Governance OR accountability OR audit OR feedback OR leadership OR supervis* OR financ* OR incentive OR "cash transfer" OR CCT OR voucher OR insurance OR "user fee*" OR exemption OR "pay for performance" OR record* OR data OR electronic "electronic data" OR "information system" OR "electronic information system" OR "electronic communication" OR "telecommunication" OR mhealth OR ehealth) AND (health OR healthcare OR maternal OR mother OR child OR newborn OR "neonat")]

Our priority was to select existing systematic reviews, which fully or partly address the $a$ priori defined district level interventions for improving quality of care for $\mathrm{MNH}$. We excluded the reviews pertaining to nursing documentation, computerized pharmacy system or those focusing on certain specific chronic illnesses only as these were not included in the scope of our review. Search was conducted in the Cochrane library and PubMed and reviews that met the inclusion criteria were selected and data was abstracted by two authors on a standardized abstraction sheet: Quality assessment of the included reviews was done using Assessment of Multiple Systematic Reviews (AMSTAR) criteria [21] as detailed in paper 2 of the series [20]. Any disagreements between the primary abstractors were resolved by the third author. For the pre-identified interventions, which did not specifically report $\mathrm{MNH}$ outcomes, we have reported the impacts on other health outcomes as reported by the review authors. Estimates are reported as relative risks (RR), risk ratios (RR), risk differences (RD) or mean differences (MD) with 95\% confidence intervals (Cl's) where available. For detailed methodology please refer to paper 1 of the series [20].

\section{Findings}

Our search identified 326 potentially relevant review titles. Further evaluation of the abstracts and full texts resulted in the inclusion of 47 eligible reviews: 14 on governance and accountability mechanisms, 7 on leadership and supervision, 11 on financial strategies and 15 on information systems (Figure 1). The overall quality of reviews ranged from 3 to 10 on the AMSTAR criteria with a median score of 8 .

\section{Governance and accountability}

We included 14 [22-35] reviews evaluating the effectiveness of governance and accountability mechanisms. The median quality score was 7.5 on AMSTAR rating scale. Most of the reviews evaluated a set of pre-selected process and outcome indicators as the outcomes reported in the individual studies varied widely. Three reviews reported MNH related outcomes [22,26,29] including immunization rates, mammography uptake, perinatal and maternal morbidity and mortality. Other reported outcomes included compliance, performance improvement and rate of prescription for generic drugs. Most of the studies included in these reviews were conducted in high income countries (HIC). The characteristics and findings of the included reviews are presented in Table 2.

The effectiveness of audit and feedback mechanisms varied widely for various outcomes ranging from nil to moderate effect. Implementation involved a baseline audit followed by rounds of audit and feedback at defined intervals. In some settings audit and feedback was provided in combination with financial incentives. Audit and feedback was found to be positively associated with childhood immunization with the effect estimate ranging from $17 \%$ absolute decrease to $49 \%$ increase. However, the exact magnitude could not be ascertained due to the limited number of low quality

\section{Table 1 Components of district level interventions}

\footnotetext{
Governance and accountability: Any systematic approach to ensure that services are accountable for delivering quality healthcare including audit and feedback mechanisms, medical registries, and continuous quality improvement tools.

Leadership and supervision: Supervision is provision of monitoring, guidance and feedback on matters of personal, professional and educational development in the context of the patient care. Good leadership involves strategic planning for the provision of services, resource allocation, and set priorities for improved performance.

Financial strategy: It involves provision of monetary benefits as a source of motivation for performing desired health related actions. Financial incentives can be user- as well as provider-directed.

Information systems: It refers to a system that captures, manages and transmits information related to the health of individuals or the activities of organizations. Two emerging components of the information systems are the electronic health records and electronic communications. Electronic health record is the provision and access to electronically retrievable health records at the point of healthcare delivery while electronic communication involves computerized communication, telephone follow-up and counseling, interactive telephone systems, after-hours telephone access, and telephone screening.
} 


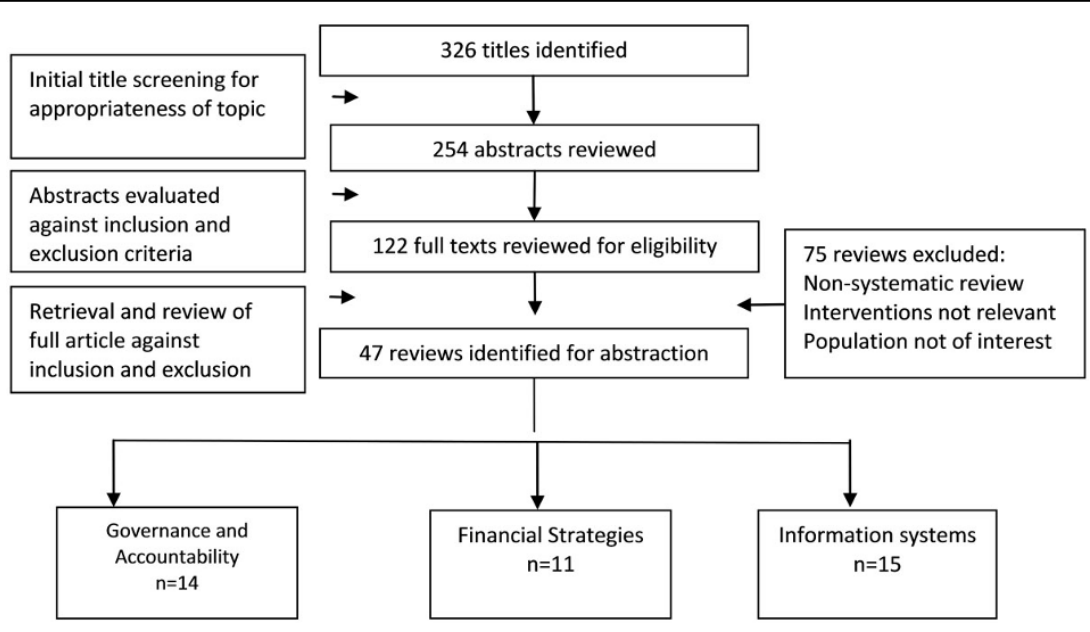

Figure 1 Search flow diagram

Table 2 Characteristics of the reviews included for governance and accountability

\begin{tabular}{|c|c|c|c|c|c|c|c|}
\hline \multirow{2}{*}{$\begin{array}{c}\text { Reviews } \\
(n=14)\end{array}$} & \multirow{2}{*}{$\begin{array}{l}\text { Description of } \\
\text { included } \\
\text { interventions }\end{array}$} & \multirow{2}{*}{$\begin{array}{l}\text { Type of } \\
\text { studies } \\
\text { included } \\
\text { (number) }\end{array}$} & \multirow{2}{*}{$\begin{array}{l}\text { Targeted health care } \\
\text { providers }\end{array}$} & \multicolumn{2}{|c|}{ Outcome reported } & \multirow{2}{*}{$\begin{array}{l}\text { Pooled } \\
\text { data } \\
(\mathrm{Y} / \mathrm{N})\end{array}$} & \multirow[t]{2}{*}{ Results } \\
\hline & & & & $\begin{array}{l}\text { Other } \\
\text { outcomes }\end{array}$ & $\begin{array}{l}\text { MNH specific } \\
\text { outcomes }\end{array}$ & & \\
\hline $\begin{array}{l}\text { Bordley } \\
2000[22]\end{array}$ & $\begin{array}{l}\text { Audit and feedback } \\
\text { was defined as any } \\
\text { summary of clinical } \\
\text { performance gathered } \\
\text { over a defined period } \\
\text { of time and presented } \\
\text { to the health care } \\
\text { provider after } \\
\text { collection. }\end{array}$ & $\begin{array}{c}\text { ITS: } 6 \\
\text { RCT: } 5 \\
\text { Pre-post: } 4\end{array}$ & $\begin{array}{l}\text { Health care } \\
\text { professionals }\end{array}$ & & $\begin{array}{l}\text { Immunization } \\
\text { rate }\end{array}$ & No & $\begin{array}{l}17 \% \text { absolute decrease } \\
\text { to } 49 \% \text { increase }\end{array}$ \\
\hline $\begin{array}{l}\text { Grimshaw } \\
2004 \text { [23] }\end{array}$ & $\begin{array}{l}\text { Audit and feedback: } \\
\text { any summary of } \\
\text { clinical performance of } \\
\text { healthcare over a } \\
\text { specified period. }\end{array}$ & $\begin{array}{l}\text { C-RCTs: } 110 \\
\text { P-RCTs: } 29 \\
\text { C-CCTs: } 7 \\
\text { PCCT: } 10 \\
\text { CBAs: } 40 \\
\text { ITS: } 39\end{array}$ & $\begin{array}{l}\text { Health care } \\
\text { professionals }\end{array}$ & $\begin{array}{l}\text { Performance } \\
\text { improvement }\end{array}$ & & No & $\begin{array}{c}\text { Absolute improvement } \\
+7.0 \% \text { (range }+1.3 \text { to } \\
+16.0 \% \text { ) (dichot process } \\
\text { measures) }\end{array}$ \\
\hline $\begin{array}{l}\text { Hulschur } \\
2001[24]\end{array}$ & $\begin{array}{l}\text { Feedback: provision of } \\
\text { a summary of clinical } \\
\text { performance after the } \\
\text { performance } \\
\text { concerned, based on } \\
\text { medical records, } \\
\text { computerized data- } \\
\text { bases or other sources } \\
\text { of information. }\end{array}$ & $\begin{array}{l}55 \text { studies: } \\
\text { RCTs:37 } \\
\text { nRCTs:18 }\end{array}$ & $\begin{array}{l}\text { Primary care } \\
\text { professionals directly } \\
\text { accessible to patients } \\
\text { for all types of health } \\
\text { problems in US }\end{array}$ & $\begin{array}{l}\text { Preventive } \\
\text { services }\end{array}$ & & No & $\begin{array}{c}\text { Absolute increase of } 3 \% \\
\text { to } 26 \%\end{array}$ \\
\hline
\end{tabular}

0.8 more visits

\begin{tabular}{|c|c|c|c|c|c|c|}
\hline $\begin{array}{c}\text { Ivers } 2012 \\
{[35]}\end{array}$ & $\begin{array}{l}\text { Audit and feedback } \\
\text { defined as any } \\
\text { summary of clinical } \\
\text { performance over a } \\
\text { specified period of } \\
\text { time }\end{array}$ & RCT: 49 & $\begin{array}{l}\text { Health care provider } \\
\text { (excluding students) }\end{array}$ & Compliance & Yes & $\begin{array}{l}\text { 4.3\% absolute increase in } \\
\text { healthcare } \\
\text { professionals'compliance } \\
\text { with desired practice } \\
\text { (dichot) }\end{array}$ \\
\hline
\end{tabular}

$1.3 \%$ absolute increase in healthcare

professionals'compliance with desired practice 
Table 2 Characteristics of the reviews included for governance and accountability (Continued)

\begin{tabular}{|c|c|c|c|c|c|c|c|}
\hline $\begin{array}{l}\text { Jamtvedt } \\
2006[25]\end{array}$ & $\begin{array}{l}\text { Audit and feedback } \\
\text { defined as any } \\
\text { summary of clinical } \\
\text { performance over a } \\
\text { specified period of } \\
\text { time }\end{array}$ & RCT: 118 & $\begin{array}{l}\text { Health care provider } \\
\text { (excluding students) }\end{array}$ & Compliance & & No & $\begin{array}{c}\text { median-adjusted risk } \\
\text { difference was 5\% (range } \\
3-11 \text { ) (dichot) } \\
\\
\text { median-adjusted } \\
\text { percentage change } \\
\text { relative to control was } \\
16 \%(5-37)\end{array}$ \\
\hline \multirow[t]{3}{*}{$\begin{array}{l}\text { Jepson } \\
2000[26]\end{array}$} & $\begin{array}{l}\text { Audit and feedback to } \\
\text { physicians on their } \\
\text { performance, and } \\
\text { sometimes that of } \\
\text { their peers }\end{array}$ & $\begin{array}{l}05 \text { studies: } \\
\text { RCTs: } 02 \\
\text { quasi-RCT:01 } \\
\text { Controlled } \\
\text { trials: } 02\end{array}$ & $\begin{array}{l}\text { All people eligible to } \\
\text { participate in a } \\
\text { screening programs as } \\
\text { defined by the entry } \\
\text { criteria for that } \\
\text { programs, included } \\
\text { population groups } \\
\text { such as pregnant } \\
\text { women, neonates, } \\
\text { children and adults in } \\
\text { US }\end{array}$ & & $\begin{array}{l}\text { Screening } \\
\text { Uptake }\end{array}$ & No & $\begin{array}{l}\text { One trial: no effect on } \\
\text { screening for occult } \\
\text { blood }\end{array}$ \\
\hline & & & & & & & $\begin{array}{c}\text { One trial and one quasi: } \\
\text { feedback more effective } \\
\text { on some tests }\end{array}$ \\
\hline & & & & & & & $\begin{array}{l}\text { Two trials: increased } \\
\text { uptake of mammograms } \\
(p<0.05)\end{array}$ \\
\hline \multirow[t]{2}{*}{$\begin{array}{l}\text { Johnston } \\
2000[27]\end{array}$} & $\begin{array}{l}\text { Clinical and Medical } \\
\text { Audit mechanisms }\end{array}$ & $\begin{array}{l}\text { Total Studies: } \\
93\end{array}$ & $\begin{array}{c}\text { All health } \\
\text { professionals, mostly } \\
\text { in UK }\end{array}$ & $\begin{array}{c}\text { Clinician's } \\
\text { perceptions of } \\
\text { benefits and } \\
\text { disadvantages } \\
\text { of audit. }\end{array}$ & & No & Narrative \\
\hline & & & & $\begin{array}{l}\text { Barriers and } \\
\text { facilitators of } \\
\text { audits. }\end{array}$ & & & \\
\hline $\begin{array}{l}\text { Oxman } \\
1995[28]\end{array}$ & $\begin{array}{l}\text { Audit and feedback: } \\
\text { Any summary of } \\
\text { clinical performance of } \\
\text { health care over a } \\
\text { specified period, with } \\
\text { or without } \\
\text { recommendations for } \\
\text { clinical action. }\end{array}$ & Total: 31 & $\begin{array}{c}\text { Health care provider } \\
\text { (excluding students) } \\
\text { in mixed country } \\
\text { setting }\end{array}$ & $\begin{array}{l}\text { Rate of } \\
\text { prescription for } \\
\text { generic drugs }\end{array}$ & & No & $\begin{array}{l}40 \% \text { increase in rate of } \\
\text { prescription }\end{array}$ \\
\hline \multirow[t]{2}{*}{$\begin{array}{l}\text { Pattinson } \\
2005[29]\end{array}$} & $\begin{array}{l}\text { Any form of audit and } \\
\text { feedback with any } \\
\text { other clearly defined } \\
\text { form of audit or } \\
\text { feedback or control } \\
\text { group }\end{array}$ & No studies & Maternity units & Time and costs & $\begin{array}{l}\text { Perinatal and } \\
\text { maternal } \\
\text { mortality and } \\
\text { morbidity } \\
\text { rates }\end{array}$ & No & No studies found \\
\hline & & & & Conflicts & & & \\
\hline $\begin{array}{l}\text { Phillips } \\
2010[30]\end{array}$ & $\begin{array}{l}\text { Clinical governance is } \\
\text { a systematic and } \\
\text { integrated approach } \\
\text { for ensuring services is } \\
\text { accountable for } \\
\text { delivering quality } \\
\text { health care. Clinical } \\
\text { governance is } \\
\text { delivered through a } \\
\text { combination of } \\
\text { strategies including: } \\
\text { ensuring clinical } \\
\text { competence, clinical } \\
\text { audit, patient } \\
\text { involvement, education } \\
\text { and training, risk } \\
\text { management, use of } \\
\text { information, and staff } \\
\text { management. }\end{array}$ & $\begin{array}{c}\text { RCTs: } 7, \\
\text { longitudinal } \\
\text { observational: } \\
11 \\
\text { Case study: } 1\end{array}$ & $\begin{array}{l}\text { Primary health care } \\
\text { providers in HIC }\end{array}$ & $\begin{array}{l}\text { Process } \\
\text { measures }\end{array}$ & & No & Narrative \\
\hline
\end{tabular}


Table 2 Characteristics of the reviews included for governance and accountability (Continued)

\begin{tabular}{|c|c|c|c|c|c|c|c|}
\hline & & & & $\begin{array}{l}\text { Outcome } \\
\text { measures }\end{array}$ & & & \\
\hline $\begin{array}{l}\text { Pyone } \\
2012[31]\end{array}$ & Not clearly defined & Total: 2 & $\begin{array}{l}\text { Staff, obstetricians and } \\
\text { community }\end{array}$ & & $\begin{array}{l}\text { Maternal } \\
\text { mortality and } \\
\text { CFR }\end{array}$ & No & Narrative \\
\hline \multirow[t]{2}{*}{$\begin{array}{c}\text { Scott } \\
2009[32]\end{array}$} & $\begin{array}{l}\text { Clinical governance } \\
\text { defined as Systematic } \\
\text { coordination and } \\
\text { promotion of activities } \\
\text { that contribute to } \\
\text { continuous } \\
\text { improvement of } \\
\text { quality of care: clinical } \\
\text { audit; clinical risk } \\
\text { management; patient/ } \\
\text { service user } \\
\text { involvement; } \\
\text { professional education } \\
\text { and development; } \\
\text { clinical effectiveness } \\
\text { research and } \\
\text { development; staff } \\
\text { focus; use of } \\
\text { information systems; } \\
\text { and institutional } \\
\text { clinical governance } \\
\text { committees. Separate } \\
\text { definition of audit and } \\
\text { feedback not given. }\end{array}$ & Total: 118 & $\begin{array}{l}\text { General Physicians, } \\
\text { mostly in HIC }\end{array}$ & Compliance & & No & $\begin{array}{l}\text { Median increase in } \\
\text { compliance } 5 \% \text { (dichot) } \\
\text { and } 16 \% \text { for continuous }\end{array}$ \\
\hline & & & & $\begin{array}{l}\text { Patient health } \\
\text { outcomes }\end{array}$ & & & \\
\hline \multirow[t]{2}{*}{$\begin{array}{c}\text { Veer } 2010 \\
{[33]}\end{array}$} & $\begin{array}{c}\text { Medical registry } \\
\text { defined as a systematic } \\
\text { and continuous } \\
\text { collection of a defined } \\
\text { data set for patients } \\
\text { with specific health } \\
\text { characteristics. }\end{array}$ & Studies:53 & $\begin{array}{l}\text { Health Care } \\
\text { Professionals }\end{array}$ & $\begin{array}{l}\text { Process } \\
\text { measures }\end{array}$ & & No & $\begin{array}{c}26 \text { of } 43 \text { process } \\
\text { measures were positively } \\
\text { influenced }\end{array}$ \\
\hline & & & & $\begin{array}{l}\text { Outcome } \\
\text { measures }\end{array}$ & & & $\begin{array}{c}5 \text { of } 36 \text { outcome } \\
\text { measures were positively } \\
\text { influenced }\end{array}$ \\
\hline $\begin{array}{l}\text { Wensing } \\
1998[34]\end{array}$ & $\begin{array}{l}\text { Any interventions } \\
\text { influencing the } \\
\text { implementation of } \\
\text { guidelines and } \\
\text { adoption of } \\
\text { innovations in general } \\
\text { practice. Feedback not } \\
\text { defined. }\end{array}$ & $\begin{array}{c}\text { Total: } 143 \\
\text { RCTs: } 39, \text { CBA: } \\
\text { 22, nRCTs: } 13 \\
\text { non } \\
\text { randomized, } \\
\text { uncontrolled } \\
\text { trials: } 67\end{array}$ & GPs in $\mathrm{HIC}$ & $\begin{array}{l}\text { Guideline } \\
\text { implementation } \\
\text { and adoption of } \\
\text { innovations }\end{array}$ & & No & $\begin{array}{c}\text { Effective in } 10 \text { of } 15 \\
\text { groups }\end{array}$ \\
\hline
\end{tabular}

design studies [22]. For the screening uptake, feedback resulted in higher proportion of physicians with completed mammograms and it was most effective when targeting test ordering and prevention activities, and when associated with low baseline adherence to recommended care or more intense feedback [26]. A review evaluating the effectiveness of maternity ward audits did not find any trial for inclusion but reported that serial data suggests benefit [29].

For outcomes other than $\mathrm{MNH}$, audit and feedback was found to improve health care workers performance and compliance with desired practice by $7 \%$ and $4.3 \%$ respectively [23,35]. It was also associated with $40 \%$ increase in rate of prescription for generic drugs [28]. Feedback involved verbal, written or both provided either by the supervisor, professional standards review organization or employer representative. Majority of the feedback provided included action plans or correct solution information with the feedback. Some of the reported factors influencing audit and feedback included problems with staff coordination, lack of strong evidence base for some topics, poor access to published work and high-quality clinical data, organizational factors and lack of time and motivation [32,33]. 


\section{Leadership and supervision}

We included seven $[28,36-41]$ reviews evaluating the impact of leadership and supervision with a median quality score of 8 on AMSTAR criteria. Included reviews focused on the impact of leadership and supervision for the primary health workers [36,37]; involvement of local community leaders [38], nursing leadership [39,41] and supervising counselors or psychotherapist [40]. Due to the wide range of reported outcomes, data could not be pooled for any outcome except for compliance in one review evaluating the impact of involving opinion leaders [38]. None of the reviews reported outcomes specific to $\mathrm{MNH}$ while other reported outcomes included compliance, patient satisfaction, provider's practice and knowledge. The evidence was from both LMIC and HIC. The characteristics and findings of the included reviews are presented in Table 3.

Involving local opinion leaders to promote evidencebased practice resulted in a $12 \%$ [RD: $12 \%, 95 \%$ CI: 6 14.5\%] absolute increase in compliance with the desired practice [38]. These opinion leaders were identified using the sociometric method in which healthcare professionals were asked to complete a self-administered questionnaire to identify educationally influential colleagues. Once identified, they were involved in informal or formal teaching through one to one teaching, community outreach education visits, small group teaching, preceptor-ships and delivering. Involving local opinion leaders was found comparable to other strategies used to disseminate and implement evidence based practice in health care including distribution of educational materials, audit and feedback and educational outreach. Another review based on a single RCT demonstrated a substantial increase in the number of trials of vaginal delivery after previous cesarean section in hospitals with the involvement of local opinion leaders [28]. The impact of supervision on the quality of primary health care in LMIC was inconclusive due to low quality studies [37]. Nursing leadership and supervision suggested improvements in patient satisfaction and reduction of adverse events; however, the evidence is inconclusive for complications and mortality rates $[39,41]$.

\section{Financial strategy}

We included 10 [12,42-50] reviews and 1 [11] overview of reviews with median data quality score of 8.5 on AMSTAR criteria. Six reviews evaluated provider-

Table 3 Characteristics of the reviews included for leadership and supervision

\begin{tabular}{|c|c|c|c|c|c|c|c|}
\hline \multirow{2}{*}{$\begin{array}{l}\text { Reviews } \\
(n=07)\end{array}$} & \multirow{2}{*}{$\begin{array}{l}\text { Description of included } \\
\text { interventions }\end{array}$} & \multirow{2}{*}{$\begin{array}{c}\text { Type of } \\
\text { studies } \\
\text { included (no) }\end{array}$} & \multirow{2}{*}{$\begin{array}{l}\text { Targeted } \\
\text { health care } \\
\text { providers }\end{array}$} & \multicolumn{2}{|c|}{ Outcome reported } & \multirow{2}{*}{$\begin{array}{l}\text { Pooled } \\
\text { data } \\
(\mathrm{Y} / \mathrm{N})\end{array}$} & \multirow[t]{2}{*}{ Results } \\
\hline & & & & Other outcomes & $\begin{array}{c}\text { MNH } \\
\text { specific } \\
\text { outcomes }\end{array}$ & & \\
\hline \multirow[t]{2}{*}{$\begin{array}{l}\text { Capblanch } \\
2008[36]\end{array}$} & $\begin{array}{l}\text { Summarize opinion about } \\
\text { what supervision of primary } \\
\text { health care is by those } \\
\text { advocating it; compare these } \\
\text { features with reports } \\
\text { describing supervision in } \\
\text { practice; appraise the } \\
\text { evidence of the effects of } \\
\text { sector performance. }\end{array}$ & $\begin{array}{l}\text { Total: } 74 \\
\text { Policy and } \\
\text { opinion } \\
\text { papers: } 08 \\
\text { Descriptive } \\
\text { Studies: } 54 \\
\text { Quasi: } 12\end{array}$ & $\begin{array}{l}\text { PHC Workers in } \\
\text { LMIC }\end{array}$ & $\begin{array}{l}\text { Health service } \\
\text { coverage }\end{array}$ & & No & $\begin{array}{c}10 \text { of } 11 \text { studies } \\
\text { showed at least one } \\
\text { outcome favoring } \\
\text { intervention. }\end{array}$ \\
\hline & & & & $\begin{array}{l}\text { Knowledge and } \\
\text { awareness }\end{array}$ & & & \\
\hline \multirow[t]{2}{*}{$\begin{array}{l}\text { Capblanch } \\
2011\end{array}$} & $\begin{array}{l}\text { Supervision is conceptualized } \\
\text { as the link between district } \\
\text { and peripheral health staff, } \\
\text { and is considered important } \\
\text { in staff motivation and } \\
\text { performance. Supervision } \\
\text { often includes aspects of } \\
\text { problem solving, reviewing } \\
\text { records and observing clinical } \\
\text { practice. } \\
\text { Supervision mostly means } \\
\text { visiting supervisees, but also } \\
\text { includes meetings in the } \\
\text { centre. }\end{array}$ & $\begin{array}{l}\text { Total: } 09 \\
\text { CRCT's: } 05 \\
\text { CBA: } 04\end{array}$ & $\begin{array}{c}\text { PHC Worker in } \\
\text { LMIC }\end{array}$ & Providers' practice & & No & $\begin{array}{l}2 \text { of } 3 \text { studies found } \\
\text { positive impact }\end{array}$ \\
\hline & & & & Providers' knowledge & & & $\begin{array}{l}1 \text { of } 3 \text { studies found } \\
\text { positive impact }\end{array}$ \\
\hline
\end{tabular}


Table 3 Characteristics of the reviews included for leadership and supervision (Continued)

\begin{tabular}{|c|c|c|c|c|c|c|c|}
\hline $\begin{array}{l}\text { Flodgren } \\
2011[38]\end{array}$ & $\begin{array}{l}\text { Opinion leaders had to be } \\
\text { identified by one of the } \\
\text { following methods: socio- } \\
\text { metric method, informant } \\
\text { method, self-designating } \\
\text { method, observation method. }\end{array}$ & RCT's: 18 & $\begin{array}{l}\text { Local opinion } \\
\text { leaders in HIC }\end{array}$ & Compliance & & Yes & RD12\% (6- 14.5\%) \\
\hline $\begin{array}{l}\text { Oxman } \\
1995[28]\end{array}$ & $\begin{array}{l}\text { Use of providers explicitly } \\
\text { nominated by their } \\
\text { colleagues to be } \\
\text { "educationally influential". }\end{array}$ & Trials: 04 & $\begin{array}{l}\text { Local opinion } \\
\text { leaders }\end{array}$ & & $\begin{array}{c}\text { No of } \\
\text { vaginal } \\
\text { deliveries }\end{array}$ & No & $\begin{array}{c}\text { Increase in number of } \\
\text { vaginal deliveries after } \\
\text { C-section in hospitals } \\
\text { where local opinion } \\
\text { leaders were involved } \\
(1 / 1) \\
\end{array}$ \\
\hline $\begin{array}{l}\text { Pearson } \\
2007[39]\end{array}$ & $\begin{array}{l}\text { Feasibility, meaningfulness } \\
\text { and effectiveness of } \\
\text { developing and sustaining } \\
\text { nursing leadership to foster a } \\
\text { healthy work environment in } \\
\text { healthcare. }\end{array}$ & $\begin{array}{c}\text { Total:48 } \\
\text { Review: } 1 \\
\text { Experimental: } \\
2 \\
\text { Descriptive } \\
\text { correlational: } \\
45\end{array}$ & $\begin{array}{l}\text { Nursing } \\
\text { Personnel }\end{array}$ & Satisfaction & & No & Narrative \\
\hline \multirow[t]{4}{*}{$\begin{array}{c}\text { Wong } \\
2007[41]\end{array}$} & $\begin{array}{l}\text { Leadership was defined as } \\
\text { the process through which } \\
\text { an individual attempts to } \\
\text { intentionally influence } \\
\text { another individual or a group } \\
\text { to accomplish a goal. }\end{array}$ & $\begin{array}{c}\text { Observational: } \\
07\end{array}$ & $\begin{array}{l}\text { Nursing } \\
\text { Personnel }\end{array}$ & Patient satisfaction & & No & $\begin{array}{c}\text { Satisfaction increased } \\
\text { in } 2 \text { of } 3 \text { (insignificant } \\
\text { in } 1 \text { ) }\end{array}$ \\
\hline & & & & $\begin{array}{l}\text { Patient mortality and } \\
\text { patient safety }\end{array}$ & & & $\begin{array}{l}\text { Mortality reduced in } 1 \\
\text { of } 3 \text { (insignificant in 2) }\end{array}$ \\
\hline & & & & Adverse events & & & $\begin{array}{l}\text { Adverse events } \\
\text { decreased in } 2 \text { of } 3 \\
\text { (insignificant in 1) }\end{array}$ \\
\hline & & & & Complications & & & $\begin{array}{l}\text { Complications } \\
\text { decreased in } 2 \text { of } 3 \\
\text { (insignificant in 1) }\end{array}$ \\
\hline $\begin{array}{l}\text { Wheeler } \\
2007[40]\end{array}$ & $\begin{array}{c}\text { Supervisors must be } \\
\text { counselors or } \\
\text { psychotherapists or other } \\
\text { professionals who have had a } \\
\text { substantial training as } \\
\text { counselors or } \\
\text { psychotherapists and who } \\
\text { were specifically engaged in } \\
\text { a counseling role with clients. }\end{array}$ & $\begin{array}{l}\text { Quantitative: } \\
\quad 08 \\
\text { Qualitative: } 03 \\
\text { Mixed: } 07\end{array}$ & $\begin{array}{l}\text { Counselors or } \\
\text { psychotherapist } \\
\text { in HIC }\end{array}$ & $\begin{array}{l}\text { Self-awareness, skills, } \\
\text { self-efficacy, timing } \\
\text { and frequency, } \\
\text { theoretical } \\
\text { orientation, support, } \\
\text { client outcomes }\end{array}$ & & No & Narrative \\
\hline
\end{tabular}

directed incentives in the form of pay for performance, economic incentives, results based financing (RBF), salary, capitation or fee-for-service (FFS); while others focused on user-directed incentives including CCTs, vouchers, health insurance or user fee exemption. Seven reviews reported outcomes specific to $\mathrm{MNH}$ while meta-analysis was conducted in only two of the reviews $[42,50]$. Reported MNH outcomes included immunization coverage, service utilization, institutional delivery, antenatal care (ANC), post natal care (PNC), skilled birth attendant, child nutritional status and anthropometry while other reported outcomes were consultation rates, compliance, prescription rates, referrals and hospital/Emergency Department (ED) visits. Most of the reviews were from LMIC. The characteristics and findings of the included reviews are presented in Table 4.
Among user directed financial strategies, CCT demonstrated significant improvements in preventive clinic visits (RR: $1.26,95 \%$ CI: 1.09, 1.45), Diphtheria, pertussis and tetanus (DPT) immunization (RR: 1.08, 95\% CI: $1.03,1.14)$, health service utilization, child nutritional status and health outcomes [42,45] with non-significant impacts on full immunization, stunting and wasting [42]. An unpublished review on the impact of a range of financial platforms on $\mathrm{MNH}$ reported significant overall impact on maternal health indicators with maternal voucher schemes (RR: 2.97, 95\% CI:2.38-3.71), user fee exemption (RR: $1.57,95 \%$ CI: 1.33-1.85) and community based health insurance (RR: 1.77, 95\% CI: 1.29-2.44) while CCTs and national health insurance (NHI) did not show any significant impacts [50]. Maternal voucher schemes were reported to be the most effective strategy 
Table 4 Characteristics of the reviews included for Financial Platforms

\begin{tabular}{|c|c|c|c|c|c|c|c|}
\hline \multirow{2}{*}{$\begin{array}{c}\text { Reviews } \\
(\mathrm{n}=11)\end{array}$} & \multirow{2}{*}{$\begin{array}{l}\text { Description of } \\
\text { included } \\
\text { interventions }\end{array}$} & \multirow{2}{*}{$\begin{array}{c}\text { Type of } \\
\text { studies } \\
\text { included } \\
\text { (no) }\end{array}$} & \multirow{2}{*}{$\begin{array}{l}\text { Targeted health care } \\
\text { providers }\end{array}$} & \multicolumn{2}{|c|}{ Outcome reported* } & \multirow{2}{*}{$\begin{array}{l}\text { Pooled } \\
\text { data } \\
\text { (Y/N) }\end{array}$} & \multirow[t]{2}{*}{ Results } \\
\hline & & & & $\begin{array}{l}\text { Other } \\
\text { outcomes }\end{array}$ & $\begin{array}{l}\text { MNH specific } \\
\text { outcomes }\end{array}$ & & \\
\hline \multirow[t]{5}{*}{$\begin{array}{l}\text { Flodgren } \\
2011[11] \\
\text { (overview) }\end{array}$} & $\begin{array}{l}\text { An incentive is any } \\
\text { factor (financial or non- } \\
\text { financial) that provides } \\
\text { motivation for a } \\
\text { particular course of } \\
\text { action, or counts as a } \\
\text { reason for preferring } \\
\text { one choice compared } \\
\text { to alternatives. } \\
\text { Financial incentives are } \\
\text { extrinsic sources of } \\
\text { motivation and exist } \\
\text { when an individual } \\
\text { receives a monetary } \\
\text { transfer which is made } \\
\text { conditional on acting } \\
\text { in a particular way }\end{array}$ & 4 reviews & $\begin{array}{l}\text { physicians, dentists, } \\
\text { nurses, and allied } \\
\text { healthcare professions } \\
\text { (such as } \\
\text { physiotherapists, } \\
\text { speech therapists etc.) } \\
\text { involved in providing } \\
\text { direct patient care in } \\
\text { LMIC and HIC }\end{array}$ & $\begin{array}{l}\text { Consultation } \\
\text { or visit rates }\end{array}$ & & No & $\begin{array}{c}\text { Improvement in 10/17 } \\
\text { outcomes }\end{array}$ \\
\hline & & & & $\begin{array}{l}\text { Processes of } \\
\text { care }\end{array}$ & & & $\begin{array}{c}\text { Improvement in } 41 / 57 \\
\text { outcomes }\end{array}$ \\
\hline & & & & $\begin{array}{l}\text { Referrals and } \\
\text { admissions }\end{array}$ & & & $\begin{array}{l}\text { Improvement in 11/16 } \\
\text { outcomes }\end{array}$ \\
\hline & & & & Compliance & & & $\begin{array}{l}\text { Improvement in 5/17 } \\
\text { outcomes }\end{array}$ \\
\hline & & & & $\begin{array}{l}\text { Prescribing } \\
\text { costs }\end{array}$ & & & $\begin{array}{c}\text { Improvement in 28/34 } \\
\text { outcomes }\end{array}$ \\
\hline \multirow[t]{5}{*}{$\underset{[42]}{\text { Gaarder } 2010}$} & $\begin{array}{l}\text { The traditional CCT } \\
\text { programs (which is } \\
\text { how we will refer to } \\
\text { the nine safety-net } \\
\text { type of programs } \\
\text { included in the study) } \\
\text { were specifically } \\
\text { designed to influence } \\
\text { demand-side factors, } \\
\text { and, in most cases, not } \\
\text { the supply-side factors }\end{array}$ & $\begin{array}{l}41 \text { studies } \\
\text { related to } 11 \\
\text { programs/ } \\
\text { interventions }\end{array}$ & General population & & Clinic visits & Yes & $1.26(1.09,1.45)$ \\
\hline & & & & & $\begin{array}{l}\text { Immunization- } \\
\text { DPT }\end{array}$ & & $1.08(1.03,1.14)$ \\
\hline & & & & & $\begin{array}{l}\text { Immunization- } \\
\text { Full }\end{array}$ & & $1.09(0.97,1.22)$ \\
\hline & & & & & $\begin{array}{l}\text { Nutritional } \\
\text { improvements- } \\
\text { stunting }\end{array}$ & & $1.04(0.92,1.18)$ \\
\hline & & & & & $\begin{array}{l}\text { Nutritional } \\
\text { improvements- } \\
\text { wasting }\end{array}$ & & $1.19(0.55,2.57)$ \\
\hline $\begin{array}{l}\text { Giuffrida } \\
1999[43]\end{array}$ & $\begin{array}{l}\text { Target payments } \\
\text { remuneration. Under a } \\
\text { target payments } \\
\text { remuneration system a } \\
\text { lump sum payment is } \\
\text { made if, and only if, } \\
\text { the PCP reaches a } \\
\text { predetermined } \\
\text { quantity or target level } \\
\text { of care. }\end{array}$ & $\begin{array}{l}\text { RCT: } 1 \\
\text { ITS: } 1\end{array}$ & $\begin{array}{l}\text { Primary Care Physicians } \\
\text { (PCPS) defined as } \\
\text { medically qualified } \\
\text { physicians who } \\
\text { provide primary health } \\
\text { care. }\end{array}$ & & $\begin{array}{l}\text { Immunization } \\
\text { rates }\end{array}$ & No & $\begin{array}{l}\text { Significant } \\
\text { improvement in } 1 \text { of } \\
2 \text { studies }\end{array}$ \\
\hline
\end{tabular}


Table 4 Characteristics of the reviews included for Financial Platforms (Continued)

\begin{tabular}{|c|c|c|c|c|c|c|c|}
\hline $\begin{array}{c}\text { Gosden } 2000 \\
{[44]}\end{array}$ & $\begin{array}{c}\text { Salary: where a lump } \\
\text { sum payment is made } \\
\text { to the PCP for a set } \\
\text { number of working } \\
\text { hours or sessions per } \\
\text { week. } \\
\text { Capitation: where a } \\
\text { payment is made to a } \\
\text { PCP for every patient } \\
\text { for whom they provide } \\
\text { care. } \\
\text { Fee-for-service (FFS): } \\
\text { where payment is } \\
\text { made to a PCP for } \\
\text { every item of service } \\
\text { or unit of care that } \\
\text { they provide. }\end{array}$ & $\begin{array}{c}\text { RCTs: } 2 \text {, BFA: } \\
2\end{array}$ & $\begin{array}{c}\text { Primary Care Physicians } \\
\text { in HIC }\end{array}$ & $\begin{array}{l}\text { Prescriptions } \\
\text { Diagnostic } \\
\text { and curative } \\
\text { services } \\
\text { Referrals } \\
\text { Health/ } \\
\text { emergency } \\
\text { department } \\
\text { visits } \\
\text { Hospitalization } \\
\text { Compliance } \\
\text { Costs }\end{array}$ & & No & Narrative \\
\hline \multirow[t]{2}{*}{$\begin{array}{l}\text { Lagarde } 2007 \\
{[12]}\end{array}$} & $\begin{array}{l}\text { effect of directly } \\
\text { transferring money to } \\
\text { households conditional } \\
\text { on some requirements, } \\
\text { at least } 1 \text { of which had } \\
\text { to be related to health } \\
\text { seeking behavior }\end{array}$ & $\begin{array}{l}\text { Total: } 10 \\
\text { RCTs:04, } \\
\text { quasi- } \\
\text { randomized } \\
\text { trial: } 01 \\
\text { controlled } \\
\text { before-and- } \\
\text { after study: } \\
1\end{array}$ & $\begin{array}{l}\text { People living in low- or } \\
\text { middle-income } \\
\text { countries, as defined } \\
\text { by the World Bank. } \\
\text { Health services and } \\
\text { institutions in LMIC }\end{array}$ & $\begin{array}{l}\text { Care seeking } \\
\text { behavior }\end{array}$ & $\begin{array}{l}\text { Immunization } \\
\text { coverage }\end{array}$ & No & $\begin{array}{l}5 / 5 \text { studies showed } \\
\text { significant } \\
\text { improvement in at } \\
\text { least } 1 \text { of the care } \\
\text { seeking outcome }\end{array}$ \\
\hline & & & & & $\begin{array}{l}\text { Anthropometric } \\
\text { and nutritional }\end{array}$ & & $\begin{array}{l}\text { 3/4 studies reported } \\
\text { significant } \\
\text { improvement } \\
\text { All programs showed } \\
\text { positive outcome }\end{array}$ \\
\hline \multirow[t]{2}{*}{$\begin{array}{c}\text { Lagarde } 2009 \\
{[45]}\end{array}$} & $\begin{array}{l}\text { Direct monetary } \\
\text { transfers made to } \\
\text { households and } \\
\text { transfers conditioned } \\
\text { on a particular } \\
\text { behavior or action (e.g. } \\
\text { visit to a health facility } \\
\text { for regular checkups). } \\
\text { Unconditional transfers } \\
\text { were not considered. }\end{array}$ & $\begin{array}{l}\text { RCT's : } 08 \text {, } \\
\text { controlled } \\
\text { before after } \\
\text { (CBA) } \\
\text { studies: } 02\end{array}$ & $\begin{array}{l}\text { People living in low- or } \\
\text { middle-income } \\
\text { countries, as defined } \\
\text { by the World Bank. } \\
\text { Health services and } \\
\text { institutions }\end{array}$ & & $\begin{array}{l}\text { Health service } \\
\text { utilization }\end{array}$ & No & $\begin{array}{c}27 \% \text { increase in } \\
\text { individuals returning } \\
\text { for voluntary HIV } \\
\text { counseling, } \\
2.1 \text { more visits per } \\
\text { day to health facilities }\end{array}$ \\
\hline & & & & & $\begin{array}{l}\text { Immunization } \\
\text { coverage }\end{array}$ & & $\begin{array}{l}11-20 \% \text { more children } \\
\text { taken to the health } \\
\text { center } \\
23-33 \% \text { more } \\
\text { children }<4 \text { yrs. } \\
\text { attending preventive } \\
\text { healthcare visits } \\
\text { 3/4 showed } \\
\text { improvement } \\
\text { (insignificant) }\end{array}$ \\
\hline
\end{tabular}


Table 4 Characteristics of the reviews included for Financial Platforms (Continued)

\begin{tabular}{|c|c|c|c|c|c|c|c|}
\hline & & & & \multirow{2}{*}{\multicolumn{2}{|c|}{$\begin{array}{c}\text { Health } \\
\text { outcomes } \\
\text { Child } \\
\text { anthropometry }\end{array}$}} & \multirow{2}{*}{\multicolumn{2}{|c|}{$\begin{array}{l}22-25 \% \text { decrease in } \\
\text { the probability of } \\
\text { children <3 years old } \\
\text { being reported ill in } \\
\text { the past month } \\
\text { 3/4 studies reported } \\
\text { improvement (1 } \\
\text { negative) }\end{array}$}} \\
\hline & & & & & & & \\
\hline \multirow[t]{2}{*}{$\begin{array}{c}\text { Oxman } 2009 \\
{[46]}\end{array}$} & $\begin{array}{l}\text { RBF can be defined as } \\
\text { the transfer of money } \\
\text { or material goods } \\
\text { conditional on taking a } \\
\text { measurable action or } \\
\text { achieving a } \\
\text { predetermined } \\
\text { performance target }\end{array}$ & & $\begin{array}{c}\text { recipients of } \\
\text { healthcare, individual } \\
\text { providers of healthcare, } \\
\text { healthcare facilities, } \\
\text { private sector } \\
\text { organizations, public } \\
\text { sector organizations, } \\
\text { sub-national } \\
\text { governments } \\
\text { (municipalities or } \\
\text { provinces), national } \\
\text { governments, or } \\
\text { multiple levels in LMIC }\end{array}$ & TB outcomes & & No & Narrative \\
\hline & & & & $\begin{array}{l}\text { Program } \\
\text { specific } \\
\text { outcomes }\end{array}$ & & & \\
\hline $\begin{array}{c}\text { Scott } 2011 \\
{[47]}\end{array}$ & $\begin{array}{l}\text { Financial incentives } \\
\text { defined in detail in } \\
\text { terms of method of } \\
\text { payment, level of } \\
\text { payment. Quality of } \\
\text { care defined broadly as } \\
\text { of "the degree to } \\
\text { which health care } \\
\text { services for individuals } \\
\text { and populations } \\
\text { increase the likelihood } \\
\text { of desired outcomes } \\
\text { and are consistent with } \\
\text { current professional } \\
\text { knowledge }\end{array}$ & $\begin{array}{c}\text { CRCT: } \\
\text { 3CBA:2 ITS: } 1\end{array}$ & $\begin{array}{c}\text { Primary care physicians } \\
\text { (PCPs): PCPs are } \\
\text { defined as doctors } \\
\text { holding } \\
\text { A medical degree and } \\
\text { include general } \\
\text { practitioners, family } \\
\text { doctors, family } \\
\text { physicians, family } \\
\text { practitioners, and other } \\
\text { generalist physicians } \\
\text { working in primary } \\
\text { healthcare settings } \\
\text { who fulfill primary } \\
\text { health care tasks }\end{array}$ & $\begin{array}{l}\text { Quality of } \\
\text { care }\end{array}$ & & & $\begin{array}{l}6 / 7 \text { studies showed } \\
\text { modest positive } \\
\text { effects on quality of } \\
\text { care for some primary } \\
\text { outcome measures, } \\
\text { but not all. One study } \\
\text { found no effect on } \\
\text { quality of care }\end{array}$ \\
\hline $\begin{array}{c}\text { Town } 2005 \\
{[48]}\end{array}$ & $\begin{array}{l}\text { The term "economic } \\
\text { incentives" describes } \\
\text { financial incentives } \\
\text { where there is an } \\
\text { increase in physician } \\
\text { income that is a } \\
\text { function of measurable } \\
\text { performance criteria. } \\
\text { These include bonus } \\
\text { payments payable on } \\
\text { the basis of number of } \\
\text { specific services } \\
\text { provided, or based on } \\
\text { the provider achieving } \\
\text { a target outcome or } \\
\text { target behavior. }\end{array}$ & RCT's: 06 & Physician in US & & $\begin{array}{c}\text { Preventive } \\
\text { services }\end{array}$ & No & $\begin{array}{c}\text { 1/6 studies reported } \\
\text { significant } \\
\text { improvement }\end{array}$ \\
\hline $\begin{array}{c}\text { Witter } 2012 \\
{[49]}\end{array}$ & $\begin{array}{l}\text { Pay for performance } \\
\text { refers to the transfer of } \\
\text { money or material } \\
\text { goods conditional on } \\
\text { taking a measurable } \\
\text { action or achieving a } \\
\text { predetermined } \\
\text { performance target }\end{array}$ & $\begin{array}{c}\text { RCT: 1, CBA: } \\
6, \\
\text { interrupted } \\
\text { time series: } \\
2\end{array}$ & $\begin{array}{c}\text { providers of healthcare } \\
\text { services (health } \\
\text { workers and facilities), } \\
\text { sub-national } \\
\text { organizations (health } \\
\text { administrations, non- } \\
\text { governmental } \\
\text { organizations or local } \\
\text { governments), national } \\
\text { governments and } \\
\text { combinations of these } \\
\text { in LMIC }\end{array}$ & & $\begin{array}{l}\text { Provider } \\
\text { performance } \\
\text { (QoC) }\end{array}$ & No & $\begin{array}{c}\text { Mixed findings from } 5 \\
\text { studies } \\
\text { Both positive and } \\
\text { negative impacts in } 2 \\
\text { studies }\end{array}$ \\
\hline
\end{tabular}




\begin{tabular}{|c|c|c|c|c|c|c|}
\hline & & & & \multicolumn{2}{|l|}{$\begin{array}{l}\text { Utilization of } \\
\text { service } \\
\text { (antenatal care) }\end{array}$} & $\begin{array}{c}\text { Mixed findings from } 4 \\
\text { studies }\end{array}$ \\
\hline & & & & \multicolumn{2}{|l|}{$\begin{array}{l}\text { Utilization of } \\
\text { service } \\
\text { (institutional } \\
\text { delivery) }\end{array}$} & $\begin{array}{l}\text { No impact on } \\
\text { preventive care }\end{array}$ \\
\hline & & & & \multicolumn{2}{|l|}{$\begin{array}{l}\text { Utilization of } \\
\text { service } \\
\text { (preventive care } \\
\text { for children) }\end{array}$} & $\begin{array}{c}\text { Immunization } \\
\text { coverage improved in } \\
4 / 4 \text { studies }\end{array}$ \\
\hline & & & & \multicolumn{2}{|l|}{$\begin{array}{l}\text { Patient } \\
\text { outcome }\end{array}$} & $\begin{array}{l}\text { Improved wasting in } \\
1 / 1 \text { study }\end{array}$ \\
\hline \multirow[t]{18}{*}{$\begin{array}{c}\text { Zaidi } 12 \\
\text { (unpublished) } \\
\text { [50] }\end{array}$} & \multirow[t]{18}{*}{$\begin{array}{l}\text { Financing platforms } \\
\text { that addressed } \\
\text { maternal care either as } \\
\text { primary objective of } \\
\text { their study or as part } \\
\text { of a larger service } \\
\text { package. Types of } \\
\text { financing strategies } \\
\text { considered for this } \\
\text { review included cash } \\
\text { transfers, vouchers, } \\
\text { contracting, } \\
\text { community health } \\
\text { insurance schemes, } \\
\text { national health } \\
\text { insurance, and user fee } \\
\text { exemption. }\end{array}$} & \multirow[t]{18}{*}{12} & \multirow[t]{18}{*}{ General population } & $\begin{array}{l}\text { Maternal } \\
\text { Voucher } \\
\text { Schemes: }\end{array}$ & Yes & $2.97(2.38-3.71)$ \\
\hline & & & & $\begin{array}{l}\text { Institutional } \\
\text { delivery }\end{array}$ & & $3.70(2.03-6.73)$ \\
\hline & & & & $\begin{array}{l}\text { Skilled birth } \\
\text { attendant }\end{array}$ & & $3.81(2.92-4.95)$ \\
\hline & & & & $\begin{array}{c}\text { Complicated } \\
\text { delivery }\end{array}$ & & $1.53(1.14-2.05)$ \\
\hline & & & & ANC & & $3.08(2.23-4.25)$ \\
\hline & & & & PNC & & $2.66(1.59-4.44)$ \\
\hline & & & & Maternal CCT: & & $0.88(0.76-1.02)$ \\
\hline & & & & $\begin{array}{l}\text { Skilled birth } \\
\text { attendant }\end{array}$ & & $0.88(0.76-1.02)$ \\
\hline & & & & $\begin{array}{l}\text { User fee } \\
\text { removal: }\end{array}$ & & $1.57(1.33-1.85)$ \\
\hline & & & & $\begin{array}{l}\text { Institutional } \\
\text { delivery }\end{array}$ & & $1.58(1.16-2.14)$ \\
\hline & & & & $\begin{array}{l}\text { Skilled birth } \\
\text { attendant }\end{array}$ & & $1.54(1.26-1.88)$ \\
\hline & & & & $\begin{array}{l}\text { National health } \\
\text { insurance: }\end{array}$ & & $1.22(0.90-1.65)$ \\
\hline & & & & ANC & & $1.04(1.01-1.07)$ \\
\hline & & & & $\begin{array}{l}\text { Institutional } \\
\text { delivery }\end{array}$ & & $1.48(0.79-2.78)$ \\
\hline & & & & $\begin{array}{l}\text { Community } \\
\text { based health } \\
\text { insurance: }\end{array}$ & & $1.77(1.29-2.44)$ \\
\hline & & & & $\begin{array}{l}\text { Institutional } \\
\text { delivery }\end{array}$ & & $3.00(1.60-5.61)$ \\
\hline & & & & ANC & & $1.41(1.22-1.63)$ \\
\hline & & & & PNC & & $0.96(0.46-2.00)$ \\
\hline
\end{tabular}


and demonstrated significant improvements across all range of outcomes including institutional delivery (RR: 3.7, 95\% CI: 2.03, 6.73), skilled birth attendance (RR: 3.81, 95\% CI: 2.92, 4.95), complicated delivery (RR: 1.53, 95\% CI: 1.14, 2.05), ANC (RR: 3.08, 95\% CI: 2.23, 4.25) and PNC (RR: 2.66, 95\% CI: 1.59, 4.44) [50].

Among provider-directed financial strategies, target payments to primary care physicians (PCP) and pay-for performance showed positive trends for immunization rates [43] while the findings were inconclusive for provider performance, service utilization, compliance or quality of primary health care $[11,43,47,49]$. We did not find any evidence for the impact on patient outcomes.

\section{Information systems}

We included fifteen [19,51-65] reviews pertaining to computerized communication, electronic health record system, telephone follow-up and counseling, interactive telephone systems, after-hours telephone access and telephone screening. The quality of included reviews ranged from 3 to 10 on AMSTAR criteria. Reported MNH outcomes included immunization rates, mammography uptake, and newborn health outcomes $[51,64]$ while other reported outcomes included technology adoption, patient satisfaction, professional behavior and knowledge. All the reviews were from HIC only. The characteristics and findings of the included reviews are presented in Table 5.

Distance communication significantly improved immunization rates (Range: 6.4\%-27.2\%) and number of mammograms (Range: 14\%-25\%) [51] with non-conclsuive evidence on the use of telemedicine to support parents of high-risk newborns receiving intensive care [64]. Distance medicine technology also reported greater continuity of care by improving access and it should not be limited to physician-to-physician communication only [51]. Evidence also suggests that telephone consultation might reduce the number of surgery contacts and out-of-hours visits by general practitioners [53,54]. All the technological aspects of the interventions were reported to be well accepted by patients with some evidence of clinical benefits [56].

There is very limited evidence on interventions to promote information communication technologies (ICT), improvements in knowledge about the electronic sources of information and use of electronic databases and digital libraries by healthcare professionals $[61,65]$. Studies examining physician use of electronic records found mostly neutral or mildly positive effects on patient satisfaction (3.7\%, 95\% CI: 2.9-5.2\%) [60] while computer based guideline implementation resulted in improved adherence [63]. No change in professional behavior was reported following electronic retrieval of health information.

\section{Discussion}

At district level, audit and feedback mechanisms can effectively improve immunization rates; healthcare worker performance and compliance with desired practice; and prescription rates for generic drugs. Generalizability of these findings are however limited to HIC only. Involving local opinion leaders in informal/formal teaching, preceptor-ship and evidence based intervention dissemination can improve compliance with the desired practice. Userdirected financial incentives have the potential to improve $\mathrm{MNH}$ outcomes, with CCT and maternal voucher schemes having the most significant positive impact across a range of outcomes. These findings are generalizable to both HIC and LMIC. There was limited and inconclusive evidence on the effectiveness of information technology

Table 5 Characteristics of the reviews included for Information System

\begin{tabular}{|c|c|c|c|c|c|c|c|}
\hline \multirow[t]{2}{*}{ Reviews ( $n=15$ ) } & \multirow{2}{*}{$\begin{array}{l}\text { Description of included } \\
\text { interventions }\end{array}$} & \multirow{2}{*}{$\begin{array}{l}\text { Type of } \\
\text { Studies } \\
\text { included } \\
\text { (no) }\end{array}$} & \multirow{2}{*}{$\begin{array}{l}\text { Targeted } \\
\text { Health care } \\
\text { Providers }\end{array}$} & \multicolumn{2}{|c|}{ Outcome reported } & \multirow{2}{*}{$\begin{array}{l}\text { Pooled } \\
\text { Data } \\
(\mathrm{Y} / \mathrm{N})\end{array}$} & \multirow[t]{2}{*}{ Results } \\
\hline & & & & Other outcomes & $\begin{array}{l}\text { MNH specific } \\
\text { outcomes }\end{array}$ & & \\
\hline \multirow[t]{2}{*}{ Black 2011 [52] } & $\begin{array}{l}\text { The researchers divided } \\
\text { e-Health technologies } \\
\text { into three main } \\
\text { categories: (1) storing, } \\
\text { managing, and } \\
\text { transmission of data; (2) } \\
\text { clinical decision support; } \\
\text { and (3) facilitating care } \\
\text { from a distance. }\end{array}$ & $\begin{array}{l}53 \\
\text { systematic } \\
\text { reviews }\end{array}$ & $\begin{array}{l}\text { Various health } \\
\text { care } \\
\text { professionals }\end{array}$ & Patient outcomes & $\begin{array}{l}\text { Electronic } \\
\text { prescribing }\end{array}$ & No & $\begin{array}{l}\text { Weak to moderate } \\
\text { effect ( } 10 \text { out of a } \\
\text { total of } 26 \text { studies) }\end{array}$ \\
\hline & & & & & $\begin{array}{l}\text { Aassociated } \\
\text { computerised } \\
\text { provider (or } \\
\text { physician) order } \\
\text { entry systems }\end{array}$ & & $\begin{array}{c}6 \text { out of a total of } 6 \\
\text { studies showed no } \\
\text { benefit }\end{array}$ \\
\hline
\end{tabular}


Table 5 Characteristics of the reviews included for Information System (Continued)

\begin{tabular}{|c|c|c|c|c|c|c|c|}
\hline \multirow[t]{3}{*}{ Gagnon 09 [65] } & $\begin{array}{l}\text { Any type of intervention } \\
\text { to promote the adoption } \\
\text { and use of any type of } \\
\text { Information } \\
\text { Communication } \\
\text { Technology (ICT) } \\
\text { (electronic medical } \\
\text { record, telemedicine/ } \\
\text { tele-health, health } \\
\text { information networks, } \\
\text { decision support tools, } \\
\text { Internet-based } \\
\text { technologies and } \\
\text { services). }\end{array}$ & $\begin{array}{l}\text { RCT: } 09 \\
\text { ITS: } 01\end{array}$ & $\begin{array}{l}\text { healthcare } \\
\text { professionals, } \\
\text { residents, } \\
\text { fellows, and } \\
\text { other registered } \\
\text { healthcare } \\
\text { professionals in } \\
\text { HIC }\end{array}$ & $\begin{array}{l}\text { Information and } \\
\text { communication } \\
\text { technology } \\
\text { adoption }\end{array}$ & & No & $\begin{array}{l}\text { Small to moderate } \\
\text { positive effect on } \\
\text { adoption }(4 / 10)\end{array}$ \\
\hline & & & & & & & $\begin{array}{c}\text { No significant } \\
\text { positive effect }(4 / 10)\end{array}$ \\
\hline & & & & & & & Mixed effect $(2 / 10)$ \\
\hline $\begin{array}{c}\text { Hayrinen } 08 \\
{[58]}\end{array}$ & $\begin{array}{l}\text { Electronic health records: } \\
\text { definitions, structure, } \\
\text { context, access, purpose } \\
\text { and methods }\end{array}$ & 89 papers & $\begin{array}{l}\text { Health care } \\
\text { professionals in } \\
\text { HIC }\end{array}$ & $\begin{array}{l}\text { Electronic health } \\
\text { records: definitions, } \\
\text { structure, context, } \\
\text { access, purpose } \\
\text { and methods }\end{array}$ & & No & Narrative \\
\hline Irani 09 [60] & $\begin{array}{l}\text { Use of Electronic health } \\
\text { record system in } \\
\text { outpatient and office } \\
\text { setting }\end{array}$ & $\begin{array}{c}\text { Cross- } \\
\text { sectional: } \\
03 \\
\text { Pre-post: } \\
04 \\
\text { (meta- } \\
\text { analyzed: } \\
\text { 03) } \\
\end{array}$ & $\begin{array}{c}\text { Physicians in } \\
\text { HIC }\end{array}$ & Patient satisfaction & & Yes & $3.7 \%(2.9-5.2 \%)$ \\
\hline \multirow[t]{2}{*}{$\begin{array}{c}\text { McGowan } 09 \\
{[61]}\end{array}$} & $\begin{array}{l}\text { Provision and access to } \\
\text { electronically retrievable } \\
\text { health records at point of } \\
\text { healthcare delivery and } \\
\text { training component }\end{array}$ & CRCT's: 02 & $\begin{array}{c}\text { Physicians, } \\
\text { nurses and } \\
\text { midwives in HIC }\end{array}$ & $\begin{array}{c}\text { Professional } \\
\text { behavior }\end{array}$ & & No & $\begin{array}{l}\text { No significant } \\
\text { change }(2 / 2)\end{array}$ \\
\hline & & & & $\begin{array}{l}\text { Improvement in } \\
\text { knowledge }\end{array}$ & & & $\begin{array}{c}\text { Improved } \\
\text { knowledge (1/2) }\end{array}$ \\
\hline \multirow[t]{4}{*}{$\begin{array}{c}\text { Ballas } 1997 \\
\text { (electronic } \\
\text { communication) } \\
{[51]}\end{array}$} & $\begin{array}{l}\text { Distance technology } \\
\text { applications were } \\
\text { described in } 6 \\
\text { categories: } \\
\text { computerized } \\
\text { communication, } \\
\text { telephone follow-up } \\
\text { and counseling, } \\
\text { telephone reminders, } \\
\text { interactive telephone } \\
\text { systems, after-hours } \\
\text { telephone access, and } \\
\text { telephone screening. }\end{array}$ & $\begin{array}{l}80 \text { clinical } \\
\text { trials }\end{array}$ & $\begin{array}{l}\text { General } \\
\text { healthcare } \\
\text { providers }\end{array}$ & $\begin{array}{l}\text { Computerized } \\
\text { communication: } \\
\text { Clinical outcomes } \\
\text { for diabetes, } \\
\text { Alzheimer's and } \\
\text { cardiac diseases }\end{array}$ & & No & $\begin{array}{c}\mathrm{HbA}_{1 \mathrm{c}} \text { decreased } \\
(4 / 4) \\
\text { Insignificant } \\
\text { changes in other } \\
\text { outcomes }\end{array}$ \\
\hline & & & & $\begin{array}{l}\text { Telephonic follow- } \\
\text { up: ED visits }\end{array}$ & & & $\begin{array}{c}\text { Significant } \\
\text { improvements in } \\
\text { keeping } \\
\text { appointment, } \\
\text { compliance, } \\
\text { follow-up care, } \\
\text { satisfaction }\end{array}$ \\
\hline & & & & Cardiac care & & & $\begin{array}{c}\text { Significant } \\
\text { improvement in } \\
\text { smoking cessation, } \\
\text { exercise, general } \\
\text { activity, knowledge }\end{array}$ \\
\hline & & & & & $\begin{array}{l}\text { Mammography } \\
\text { use }\end{array}$ & & $\begin{array}{c}\text { Significant increase } \\
\text { in no of } \\
\text { mammograms } \\
\text { (Range: } 14 \%-25 \% \text { ) }\end{array}$ \\
\hline
\end{tabular}


Table 5 Characteristics of the reviews included for Information System (Continued)

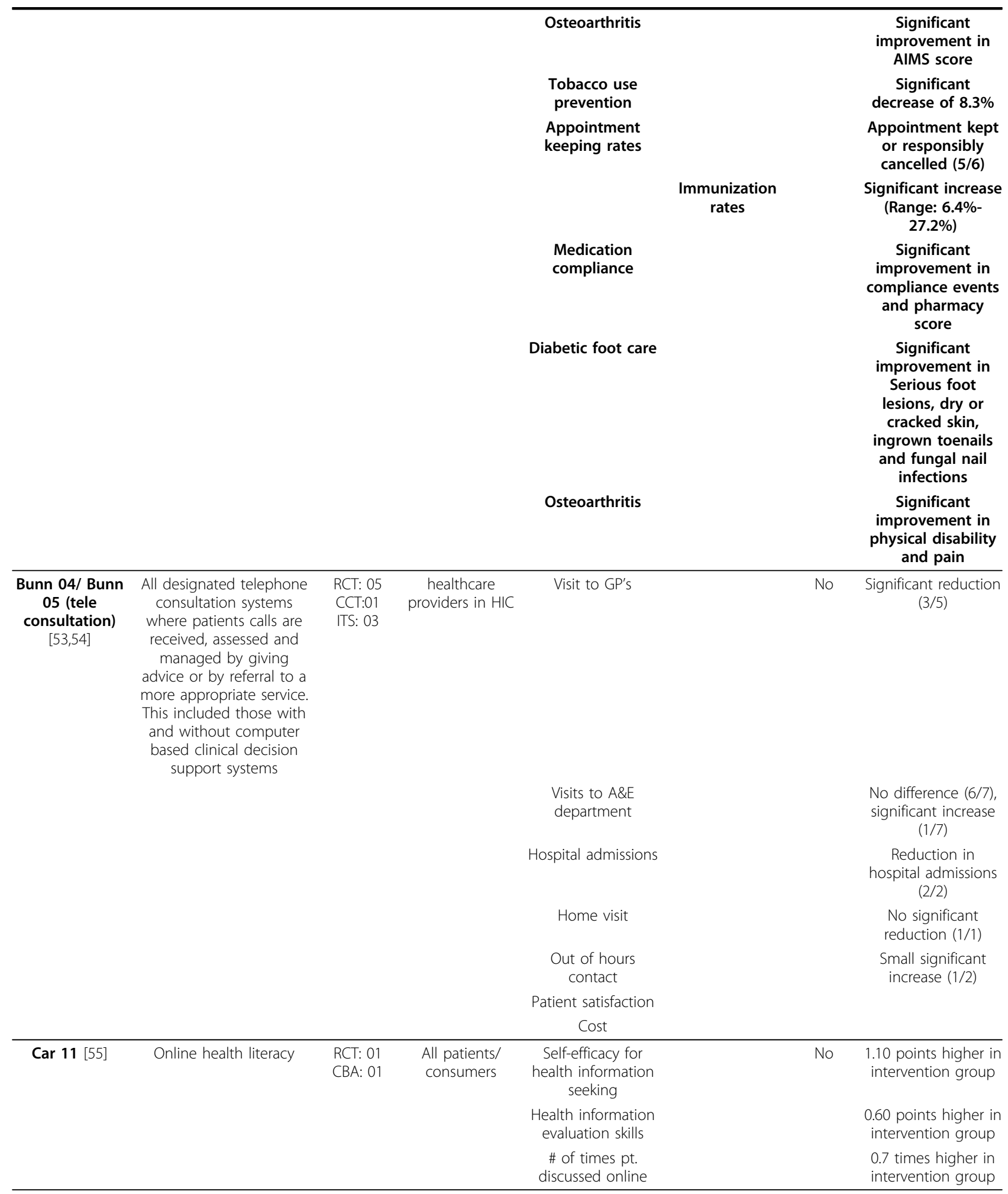


Table 5 Characteristics of the reviews included for Information System (Continued)

\begin{tabular}{|c|c|c|c|c|c|c|}
\hline \multirow[t]{5}{*}{$\begin{array}{c}\text { Currell 00 } \\
\text { (telemedicine) } \\
{[56]}\end{array}$} & $\begin{array}{l}\text { Studies which compare } \\
\text { the provision of patient } \\
\text { care face to face with } \\
\text { care given using } \\
\text { telecommunications } \\
\text { technologies, in which at } \\
\text { least two communication } \\
\text { media are used } \\
\text { interactively (e.g. video } \\
\text { consultation between } \\
\text { hospital consultant and } \\
\text { general practitioner). }\end{array}$ & Trials: 07 & $\begin{array}{c}\text { Qualified } \\
\text { healthcare } \\
\text { practitioners } \\
\text { from any } \\
\text { discipline in HIC }\end{array}$ & $\begin{array}{l}\text { Measurable } \\
\text { difference in } \\
\text { outcome of care }\end{array}$ & No & $\begin{array}{l}\text { No unequivocal } \\
\text { benefit }(7 / 7)\end{array}$ \\
\hline & & & & $\begin{array}{c}\text { Economic } \\
\text { consequence }\end{array}$ & & \\
\hline & & & & $\begin{array}{l}\text { Acceptability of } \\
\text { care }\end{array}$ & & \\
\hline & & & & $\begin{array}{l}\text { Difference in } \\
\text { professional } \\
\text { practice }\end{array}$ & & \\
\hline & & & & $\begin{array}{l}\text { Difference in } \\
\text { transfer of care }\end{array}$ & & \\
\hline Grilli 02 & Mass media & ITS: 20 & $\begin{array}{l}\text { Healthcare } \\
\text { providers } \\
\text { patients and } \\
\text { general public }\end{array}$ & Effectiveness & No & $\begin{array}{c}\text { Effective in } \\
\text { improving } \\
\text { healthcare utilization } \\
\text { (7/7 studies) }\end{array}$ \\
\hline \multirow[t]{2}{*}{$\underset{[59]}{\text { Heselmans } 09}$} & $\begin{array}{c}\text { An electronic guideline } \\
\text { implementation method } \\
\text { was defined as an } \\
\text { electronic system directly } \\
\text { supporting evidence- } \\
\text { based clinical decision } \\
\text { making in which point-of } \\
\text { care advice is provided } \\
\text { based on one or more } \\
\text { CPGs }\end{array}$ & $\begin{array}{c}20 \mathrm{CRCT}, 1 \\
\mathrm{CCT}, 2 \\
\mathrm{CBA}\end{array}$ & physicians & Patient outcomes & No & $\begin{array}{c}7 / 23 \text { studies had } \\
>50 \% \text { of the process } \\
\text { outcomes } \\
\text { significantly } \\
\text { improved }\end{array}$ \\
\hline & & & & Process outcomes & & \\
\hline \multirow[t]{7}{*}{$\begin{array}{l}\text { Mistiaen } 06 \\
\text { (telephone } \\
\text { follow-ups) [62] }\end{array}$} & $\begin{array}{l}\text { Telephone follow-up } \\
\text { (TFU) initiated by a } \\
\text { hospital-based health } \\
\text { professional (medical, } \\
\text { nursing, social work, } \\
\text { pharmaceutical) to a } \\
\text { patient who is } \\
\text { discharged to his/her } \\
\text { own home setting } \\
\text { (including a relative's } \\
\text { home). }\end{array}$ & $\begin{array}{l}33 \text { RCT's }^{\prime} \\
\text { and } \\
\text { controlled } \\
\text { trials }\end{array}$ & $\begin{array}{l}\text { hospital based } \\
\text { healthcare } \\
\text { professional in } \\
\text { HIC }\end{array}$ & $\begin{array}{l}\text { Compliance in } \\
\text { cardiac surgery } \\
\text { patients }\end{array}$ & & $1.68[0.59,4.78]$ \\
\hline & & & & $\begin{array}{l}\text { Compliance in ED } \\
\text { patients (making } \\
\text { an appointment) }\end{array}$ & & $1.68[0.59,4.78]$ \\
\hline & & & & $\begin{array}{l}\text { Compliance in ED } \\
\text { patients (keeping } \\
\text { an appointment) }\end{array}$ & & $1.58[1.01,2.48]$ \\
\hline & & & & $\begin{array}{c}\text { Effect on } \\
\text { knowledge in } \\
\text { cardiac patients }\end{array}$ & & $1.44[-0.25,3.13]$ \\
\hline & & & & $\begin{array}{c}\text { Effect on } \\
\text { readmission(cardiac } \\
\text { patients) }\end{array}$ & & $0.75[0.41,1.36]$ \\
\hline & & & & $\begin{array}{l}\text { Effect on } \\
\text { readmission in } \\
\text { surgery patients }\end{array}$ & & $0.65[0.28,1.55]$ \\
\hline & & & & $\begin{array}{l}\text { ED visits in surgery } \\
\text { patients }\end{array}$ & & $1.47[0.85,2.53]$ \\
\hline
\end{tabular}


Table 5 Characteristics of the reviews included for Information System (Continued)

\begin{tabular}{|c|c|c|c|c|c|c|c|}
\hline$\underset{\text { [19] }}{\text { Noordam } 11}$ & $\begin{array}{l}\text { The potential of mobile } \\
\text { phones to improve } \\
\text { maternal health services } \\
\text { in Low and Middle } \\
\text { Income Countries }\end{array}$ & Projects & LMIC & $\begin{array}{c}\text { Accessing } \\
\text { emergency } \\
\text { obstetric care, } \\
\text { improving the } \\
\text { capacity of lesser } \\
\text { trained health } \\
\text { workers, } \\
\text { empowering } \\
\text { women }\end{array}$ & & No & Narrative \\
\hline \multirow[t]{2}{*}{$\underset{[63]}{\text { Shiffman }} 99$} & $\begin{array}{l}\text { Computer based } \\
\text { guideline } \\
\text { implementation }\end{array}$ & $\begin{array}{c}\text { RCT: } 9 \\
\text { NRCT: } 01 \\
\text { time series: } \\
10\end{array}$ & $\begin{array}{c}\text { clinicians and } \\
\text { other } \\
\text { information } \\
\text { providers in HIC }\end{array}$ & $\begin{array}{l}\text { Guideline } \\
\text { adherence }\end{array}$ & & No & $\begin{array}{c}\text { Improved in } 14 \text { of } \\
18 \text { studies }\end{array}$ \\
\hline & & & & Documentation & & & $\begin{array}{c}\text { Improved in } 4 \text { of } 4 \\
\text { studies. }\end{array}$ \\
\hline $\begin{array}{c}\text { Tan } 12 \\
\text { (telemedicine) } \\
{[64]}\end{array}$ & $\begin{array}{l}\text { Telemedicine technology } \\
\text { focused on education } \\
\text { and support to the } \\
\text { parents or caretakers of } \\
\text { newborn infants } \\
\text { receiving intensive care. }\end{array}$ & $1 \mathrm{RCT}$ & $\begin{array}{l}\text { NICU staff in } \\
\text { Indonesia }\end{array}$ & & $\begin{array}{l}\text { Length of } \\
\text { hospital stay }\end{array}$ & Yes & $-2.10(-18.85-14.65)$ \\
\hline
\end{tabular}

with some positive impacts of distance communication on immunization rates and screening uptake. Evidence for structured interventions requiring electronic technologies are mainly evaluated in HIC settings hence limiting the generalizability of these findings to HIC only. This might be attributable to the gaps in access to and simultaneous underutilization of the existing electronic information resources in LMIC. Likewise, even within HIC, inequity exists in online information access between professionals in rural versus urban health settings.

There is a dearth of evidence from MNH perspectives in some domains of the district level inputs. Although financial incentives have been widely evaluated for their effectiveness in improving MNH outcomes; audits, feedbacks and information systems are mostly evaluated for general health outcomes. Furthermore, it is challenging to systematically measure and analyze data for subjective outcomes like patient/provider satisfaction and other process indicators. Reviews focusing on $\mathrm{MNH}$ specific interventions like maternal and perinatal mortality audits report lack of data to evaluate their effectiveness. There is also lack of qualitative data describing the individual components of the intervention for reproducibility since most of the interventions are not uniform but rather a range of approaches. For example, studies have not reported on the optimal format and frequency of audit and feedback [22]; supervision was also reported to be implemented in various ways with uncertain follow up periods [36,37].

Most of the district level interventions require a preexisting primary health care service infrastructure and measures to ensure sustainability hence the major challenge is to ensure adequate political, financial, human and material commitments; optimal use of available resources; utilization of advanced technologies, changing management techniques including decentralization; measures to ensure accountability and effective community participation and intersectoral collaboration [66]. Hence it requires involvement of several stakeholders including policy makers, program managers and service providers from government organizations, private organizations, health development partners, technical assistance agencies, district directors and service providers. State leaders and key actors in the health sectors in LMIC along with the international community are proposed to translate the lessons learnt into actions and intensify efforts in order to achieve the goals set for MNH [67]. In LMIC, district health systems are still deprived of sustained policy attention and resources that it deserves, although more recently various forms of public private partnerships to improve MNH have emerged in LMIC whereby private organizations provide financial and technical support to refurbish and enhance the health services provided by the public sector but they are not formally evaluated for its impact.

Focus on basic primary health care interventions at the district level to improve coverage of effective public health interventions will help direct the attention towards essential preventive and promotive interventions and commodities required to deliver quality care to mothers and newborns [68]. Interventions like maternal and perinatal mortality audits and distance communication should be evaluated for effectiveness in improving $\mathrm{MNH}$ outcomes at the district level. Successfully implemented programs based on financial incentives to improve maternal and child health outcomes from Africa and Latin America can be simulated in other LMIC $[12,50]$. For these strategies to be more effective, it must be part of appropriate package of interventions, and technical 
capacity or support must be available. Programs integrating multiple interventions have shown maximum benefits on $\mathrm{MNH}$ outcomes as there is no single magic bullet intervention for reducing maternal and neonatal mortality [67]. These packages should then be monitored for possible unintended effects and evaluated using rigorous study designs to identify the best possible combination of the strategies tailored to the need of the district.

\section{Author contributions}

All authors contributed to the process and writing of the manuscript.

\section{Peer review}

Peer review reports are included in Additional file 1.

\section{Additional material}

Additional file 1:

\begin{abstract}
Abbreviations
ANC: Antenatal care; AMSTAR: Assessment of Multiple Systematic Reviews; CCT: Conditional Cash Transfers; Cl: Confidence Interval; CQI: Continuous Quality Improvement; ED: Emergency Department; FFS: Fee for Service; HIC: High Income Countries; ICT: Information Communication Technology; IMCI: Integrated Management of Childhood IIInesses; LMIC: Low Middle Income Countries; MD: Mean Difference; MNH: Maternal Newborn; NHI: National Health Insurance; PCP: Primary Care Physicians; PNC: Postnatal Care; RBF: Result Based Financing; RD: Rate Difference; RR: Relative Risk;
\end{abstract}

\section{Competing interests}

We do not have any financial or non-financial competing interests for this review.

\section{Acknowledgments}

This work was supported by a grant from the Maternal health Task Force (MHTF) at the Harvard School of Public Health. We would like to acknowledge Waleed Zahid who helped us in the search and abstraction of data.

\section{Declarations}

This article has been published as part of Reproductive Health Volume 11 Supplement 2, 2014: Quality of Care in Maternal and Child Health. The full contents of the supplement are available online at http://www.reproductivehealth-journal.com/supplements/11/S2.

\section{Authors' details}

'Division of Women \& Child Health, Aga Khan University, Karachi, Pakistan.

${ }^{2}$ Program for Global Pediatric Research, Hospital For Sick Children, Toronto.

Published: 4 September 2014

\section{References}

1. Lassi, et al: Paper 2: Evidence from community level inputs to improve quality of care for maternal and newborn health: Interventions and Findings.

2. Grimshaw JM, Shirran L, Thomas R, Mowatt G, Fraser C, Bero L, Grilli R, Harvey E, Oxman A, O'Brien MA: Changing provider behavior: an overview of systematic reviews of interventions. Med Care 2001, 39(8 Suppl 2):112-45.

3. Jamtvedt G, Young JM, Kristoffersen DT, O'Brien MA, Oxman AD: Audit and feedback: effects on professional practice and health care outcomes. Cochrane Database Syst Rev 2006, 2(2):CD000259.
4. Gopee N: Mentoring and supervision in healthcare. Sage Publications; 2011

5. McMahon $\mathrm{R}$, Barton $\mathrm{E}$, Piot $\mathrm{M}$ : On being in charge. A guide to management in primary health care. Geneva: WHO; 21992.

6. Flahault D, Piot M, Franklin A: The supervision of health personnel at district level. Geneva: World Health Organization; 1988.

7. Jasper M, Jumaa M: Effective healthcare leadership. John Wiley \& Sons; 2008

8. Kleczkowski BM, Elling RH, Smith DL: Health system support for primary health care. A study based on the technical discussions held during the thirty-fourth World Health Assembly, 1981. Public Health Papers 1984, 80:1-104.

9. Grol R, Grimshaw J: Evidence-based implementation of evidence-based medicine. Jt Comm J Qual Improv 1999, 25(10):503-513.

10. Rogers EM: New product adoption and diffusion. Journal of Consumer Research 1976, 2:290-301.

11. Flodgren G, Eccles MP, Shepperd S, Scott A, Parmelli E, Beyer FR: An overview of reviews evaluating the effectiveness of financial incentives in changing healthcare professional behaviours and patient outcomes. Cochrane Database Syst Rev 2011, 7(7):CD009255.

12. Lagarde $M$, Haines $A$, Palmer $N$ : Conditional cash transfers for improving uptake of health interventions in low-and middle-income countries. JAMA 2007, 298(16):1900-1910.

13. Lim SS, Dandona L, Hoisington JA, James SL, Hogan MC, Gakidou E: India's Janani Suraksha Yojana, a conditional cash transfer programme to increase births in health facilities: an impact evaluation. Lancet 2010, 375(9730):2009-2023.

14. World Health Organization: Strengthening Health Systems to Improve Health Outcomes: WHO's Framework for Action. Geneva: World Heatlh Organization; 2007

15. MAMA-Mobile Alliance for Maternal Action: Program Website: [http:// mobilemamaalliance.org/]. 2013, Accessed September 3.

16. Bhutta ZA, Lassi ZS, Blanc A, Donnay F: Linkages among reproductive health, maternal health, and perinatal outcomes. Seminars in perinatology Elsevier; 2010, 434-445

17. Leveraging mobile technologies to promote maternal \& newborn health: The current landscape \& opportunities for advancement in lowresource settings. Center for Innovation \& Technology in Public Health. mHealth Alliance 2012, http://www.healthunbound.org/sites/default/files/ uploads/

leveraging_mobile_technologies_to_promote_maternal_newborn_health. pdf Accessed Sept. 2, 2013

18. Mechael PN: MoTECH: mHealth Ethnography Report. Dodowa Health Research Center for The Grameen Foundation Washington DC; 2009, Available at: http://www.grameenfoundation.applab.org/uploads/ Grameen_Foundation_FinalReport_3_.pdf.

19. Noordam AC, Kuepper BM, Stekelenburg J, Milen A: Improvement of maternal health services through the use of mobile phones. Tropical Medicine \& International Health 2011, 16(5):622-626.

20. Austin A, et al: Paper 1: Approaches to Improve Quality of Maternal and Newborn Health Care: An Overview of the Evidence.

21. Shea BJ, Grimshaw JM, Wells GA, Boers M, Andersson N, Hamel C, Porter AC, Tugwell P, Moher D, Bouter LM: Development of AMSTAR: a measurement tool to assess the methodological quality of systematic reviews. BMC Med Res Methodol 2007, 7:10.

22. Bordley WC, Chelminski A, Margolis PA, Kraus R, Szilagyi PG, Vann JJ: The effect of audit and feedback on immunization delivery: a systematic review. Am J Prev Med 2000, 18(4):343-350.

23. Grimshaw JM, Thomas R, MacLennan G, Fraser C, Ramsay C, Vale L, et al: Effectiveness and efficiency of guideline dissemination and implementation strategies. Health Technol Assess 2004, 8:1-72.

24. Hulscher M, Wensing M, Weijden T, Grol R: Interventions to implement prevention in primary care. Cochrane Database Syst Rev 2001, 2(2): CD000362.

25. Jamtvedt G, Young JM, Kristoffersen DT, O'Brien MA, Oxman AD: Does telling people what they have been doing change what they do? A systematic review of the effects of audit and feedback. Qual Saf Health Care 2006, 15(6):433-436

26. Jepson R, Clegg A, Forbes C, Lewis R, Sowden A, Kleijnen J: The determinants of screening uptake and interventions for increasing uptake: a systematic review. Health Technol Assess 2000, 4(14):1-133. 
27. Johnston G, Crombie IK, Alder EM, Davies HTO, Millard A: Reviewing audit: barriers and facilitating factors for effective clinical audit. Quality Health Care 2000, 9(1):23-36.

28. Oxman AD, Thomson MA, Davis DA, Haynes RB: No magic bullets: a systematic review of 102 trials of interventions to improve professional practice. CMAJ 1995, 153(10):1423-1431.

29. Pattinson RC, Say L, Makin JD, Bastos MH: Critical incident audit and feedback to improve perinatal and maternal mortality and morbidity. Cochrane Database Syst Rev 2005, 4(4):CD002961.

30. Phillips CB, Pearce CM, Hall S, Travaglia J, de Lusignan S, Love T, Kljakovic M: Can clinical governance deliver quality improvement in Australian general practice and primary care? A systematic review of the evidence. Med J Aust 2010, 193(10):602-607.

31. Pyone $\mathrm{T}$, Sorensen BL, Tellier S: Childbirth attendance strategies and their impact on maternal mortality and morbidity in lowâ€ income settings: a systematic review. Acta Obstetricia et Gynecologica Scandinavica

32. Scott I: What are the most effective strategies for improving quality and safety of health care? Intern Med J 2009, 39(6):389-400.

33. Van Der Veer SN, De Keizer NF, Ravelli ACJ, Tenkink S, Jager KJ: Improving quality of care. A systematic review on how medical registries provide information feedback to health care providers. Int J Med Inform 2010, 79(5):305-323.

34. Wensing M, van der Weijden T, Grol R: Implementing guidelines and innovations in general practice: which interventions are effective? $\mathrm{Br} J$ Gen Pract 1998, 48(427):991-997.

35. Ivers N, Jamtvedt G, Flottorp S, Young JM, Odgaard-Jensen J, French SD, O'Brien MA, Johansen M, Grimshaw J, Oxman AD: Audit and feedback: effects on professional practice and healthcare outcomes. Cochrane Database Syst Rev 2012, 6:CD000259.

36. Bosch-Capblanch X, Garner P: Primary health care supervision in developing countries. Trop Med Int Health 2008, 13(3):369-383.

37. Bosch-Capblanch X, Liaqat S, Garner P: Managerial supervision to improve primary health care in low-and middle-income countries. Cochrane Database Syst Rev 2011, 9(9):CD006413.

38. Flodgren G, Parmelli E, Doumit G, Gattellari M, O'Brien MA, Grimshaw J, Eccles MP: Local opinion leaders: effects on professional practice and health care outcomes. Cochrane Database Syst Rev 2011, 8(8):CD000125.

39. Pearson $\mathrm{A}$, Laschinger $\mathrm{H}$, Porritt $\mathrm{K}$, Jordan Z, Tucker D, Long L: Comprehensive systematic review of evidence on developing and sustaining nursing leadership that fosters a healthy work environment in healthcare. Int J Evid Based Healthc 2007, 5(2):208-253.

40. Wheeler $S$, Richards $K$ : The impact of clinical supervision on counsellors and therapists, their practice and their clients. A systematic review of the literature. Counselling and Psychotherapy Research 2007, 7(1):54-65.

41. Wong CA, Cummings GG: The relationship between nursing leadership and patient outcomes: a systematic review. J Nurs Manag 2007, 15(5):508-521.

42. Gaarder MM, Glassman A, Todd JE: Conditional cash transfers and health: unpacking the causal chain. Journal of Development Effectiveness 2010, 2(1):6-50.

43. Giuffrida A, Gosden T, Forland F, Kristiansen IS, Sergison M, Leese B, Pedersen L, Sutton M: Target payments in primary care: effects on professional practice and health care outcomes. Cochrane Database Syst Rev 1999, 4(4):CD000531.

44. Gosden T, Forland F, Kristiansen IS, Sutton M, Leese B, Giuffrida A, Sergison M, Pedersen L: Capitation, salary, fee-for-service and mixed systems of payment: effects on the behaviour of primary care physicians. Cochrane Database Syst Rev 2000, 3(3):CD002215.

45. Lagarde M, Haines A, Palmer N: The impact of conditional cash transfers on health outcomes and use of health services in low and middle income countries. Cochrane Database Syst Rev 2009, 4(4):CD008137.

46. Oxman $A D$, Fretheim $A$ : Can paying for results help to achieve the Millennium Development Goals? Overview of the effectiveness of resultsâ€ based financing. J Evid Based Med 2009, 2(2):70-83.

47. Scott A, Sivey P, Ait Ouakrim D, Willenberg L, Naccarella L, Furler J, Young D: The effect of financial incentives on the quality of health care provided by primary care physicians. Cochrane Database Syst Rev 2011, 9(9):CD008451.

48. Town R, Kane R, Johnson P, Butler M: Economic incentives and physicians' delivery of preventive care: a systematic review. Am J Prev Med 2005, 28(2):234-240.
49. Witter S, Fretheim A, Kessy FL, Lindahl AK: Paying for performance to improve the delivery of health interventions in lowâ€ and middleâ€ income countries. Cochrane Database Syst Rev 2012, 2(2):CD007899.

50. Zaidi S, Sheikh S, Bhutta ZB, Salam R: Financing Support Platforms for BMONC and CMONC: A Global Landscape Review. 2012, (unpublished).

51. Balas EA, Jaffrey F, Kuperman GJ, Boren SA, Brown GD, Pinciroli F, Mitchell JA: Electronic communication with patients. JAMA 1997, 278(2):152-159.

52. Black AD, Car J, Pagliari C, Anandan C, Cresswell K, Bokun T, McKinstry B, Procter R, Majeed A, Sheikh A: The impact of eHealth on the quality and safety of health care: a systematic overview. PLoS Med 2011, 8(1): e1000387.

53. Bunn F, Byrne G, Kendall S: Telephone consultation and triage: effects on health care use and patient satisfaction. Cochrane Database Syst Rev 2004, 3(3):CD004180.

54. Bunn F, Byrne G, Kendall S: The effects of telephone consultation and triage on healthcare use and patient satisfaction: a systematic review. $\mathrm{Br}$ J Gen Pract 2005, 55(521):956.

55. Car J, Lang B, Colledge A, Ung C, Majeed A: Interventions for enhancing consumers' online health literacy. Cochrane Database Syst Rev 2011, 6(6): CD007092.

56. Currell $R$, Urquhart $C$, Wainwright $P$, Lewis $R$ : Telemedicine versus face to face patient care: effects on professional practice and health care outcomes. Cochrane Database Syst Rev 2000, 2(2):CD002098.

57. Grilli R, Ramsay C, Minozzi S: Mass media interventions: effects on health services utilisation. Cochrane Database Syst Rev 2002, 1(1):CD000389.

58. Hayrinen K, Saranto K, Nykanen P: Definition, structure, content, use and impacts of electronic health records: a review of the research literature. Int J Med Inform 2008, 77(5):291-304.

59. Heselmans A, Van de Velde S, Donceel P, Aertgeerts B, Ramaekers D: Effectiveness of electronic guideline-based implementation systems in ambulatory care settings-a systematic review. Implement Sci 2009, 4(1):82.

60. Irani JS, Middleton JL, Marfatia R, Omana ET, D'Amico F: The use of electronic health records in the exam room and patient satisfaction: a systematic review. J Am Board Fam Med 2009, 22(5):553-562.

61. McGowan JL, Grad R, Pluye P, Hannes K, Deane K, Labrecque M, Welch V, Tugwell $P$ : Electronic retrieval of health information by healthcare providers to improve practice and patient care. Cochrane Database Syst Rev 2009, 3(3):CD004749.

62. Mistiaen P, Poot E: Telephone follow-up, initiated by a hospital-based health professional, for postdischarge problems in patients discharged from hospital to home. Cochrane Database Syst Rev 2006, 4(4):CD004510.

63. Shiffman RN, Liaw Y, Brandt CA, Corb GJ: Computer-based Guideline Implementation Systems A Systematic Review of Functionality and Effectiveness. Journal of the American Medical Informatics Association 1999, 6(2):104-114

64. Tan K, Lai NM: Telemedicine for the support of parents of high risk newborn infants. Cochrane Database Syst Rev 2012, 6(6):CD006818.

65. Gagnon MP, Legare F, Labrecque M, Fremont P, Pluye P, Gagnon J, Car J, Pagliari $C$, Desmartis $M$, Turcot $L$ : Interventions for promoting information and communication technologies adoption in healthcare professionals. Cochrane Database Syst Rev 2009, 1(1):CD006093.

66. World Health Organization: Technical Paper: Primary Health Care: 25 years after Alma-Ata. Regional Committee for the Eastern Mediterranean. Fiftieth Session, EM/RC50/8 2003, 1-21[http://gis.emro.who. int/ HealthSystemObservatory/. . ./TechnicalandDiscussionPapers/].

67. Nyamtema AS, Urassa DP, van Roosmalen J: Maternal health interventions in resource limited countries: a systematic review of packages, impacts and factors for change. BMC Pregnancy Childbirth 2011, 11:30.

68. Disease control priorities project: Health System Performance In Developing Countries: Management Matters, Not Just Resources. 2006, Accesses from http://www.dcp2.org/file/2/DCPP-HealthSystemPerf.pdf on 05/23/2013.

doi:10.1186/1742-4755-11-S2-S3

Cite this article as: Salam et al:: Evidence from district level inputs to improve quality of care for maternal and newborn health: interventions and findings. Reproductive Health 2014 11(Suppl 2):S3. 